\title{
定在波音場を用いた産業廃棄物分別方法の開発
}

\author{
稲田 智広 ${ }^{* 1}$, 周 立波 ${ }^{* 2}$, 尾嶌 裕隆 ${ }^{* 2}$, 清水 淳 ${ }^{* 2}$
}

\section{Development of separation method for industrial waste by using acoustic standing wave field}

\author{
Tomohiro INADA ${ }^{* 1}$, Libo ZHOU ${ }^{* 2}$, Hirotaka OJIMA ${ }^{* 2}$ and Jun SHIMIZU ${ }^{* 2}$

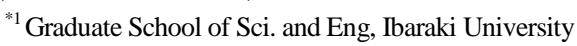 \\ 4-12-1 Nakanarusawa-cho, Hitachi-shi, Ibaraki 316-8511, Japan \\ ${ }^{* 2}$ School of Engineering, Ibaraki University \\ 4-12-1 Nakanarusawa-cho, Hitachi-shi, Ibaraki 316-8511, Japan
}

Received 26 January 2016

\begin{abstract}
In recent years, more than 10 million tons of industrial wastes are discarded annually. Those wastes are mainly composed of plastic, glass and metals which are the materials massively used in automobiles, electric and electronic products. It is well known that industrial waste contain precious metals like gold and have a great value of reutilization. Therefore, technology to properly separate the waste by their types of subject is very important for recycling industry. In this study, we have developed a new separation method by use of acoustic levitation phenomenon in a standing wave field. Unlike the conventional methods such as centrifugal particle separation or magnetic separation, this method enables to sort subjects by their densities, without relying on other material properties including size, magnetism and weight. First described in this paper is a theoretical analysis of levitation force exerted on an object to derive its trajectory in a standing wave field. It is found that the motion of the object is governed by its density and the strength of acoustic field. Based on this finding, we developed a prototype of separation system with twin-transducers and a belt conveyer. As a result of test to separate a mixture of $\mathrm{SiO}_{2}$ and $\mathrm{Fe}$ particles, $62 \mathrm{wt} \% \mathrm{SiO}_{2}$ is captured at node side while $72 \mathrm{wt} \% \mathrm{Fe}$ is captured at anti-node side. Finally, the prototype is used to repeatedly separate the chipped waste of actual OA equipment. Its density was increased about $150 \%$.
\end{abstract}

Key words : Acoustic levitation, Standing wave, Separating, Sorting, Industrial waste

\section{1. 緒 言}

近年，金属やプラスチックなどを多く含む自動車や冷蔵庫，あるいはテレビ，OA 機器などの工業廃棄物は， 年間 1006 万トン（環境省，2014）にも達している．また，この中で金をはじめとする貴金属は電子製品の導電体 として多く用いられており，再利用価值が高いために回収技術の開発が盛んに行われている（荒木他，2005）。 効率よく貴金属を回収するためには予めプラスチックやガラスなどが混合した状態から金属を多く含んだ密度の 大きい資源成分を摘出する必要がある，それらは処理をする際，小さく砕かれている小片から磁選機によって磁 性金属とプラスチック類に分別する方法が最も一般的である。しかし，この方法では磁性金属を取り出すことは できるが，アルミ，銅，金など非磁性金属は取り出すことができないという問題点がある.

本研究室では，これまで音響浮揚を利用した応用技術の開発を行っている（Inada et al., 2013）。音響浮揚は液中 の気泡や物体を音圧のノードに補足することが可能であり，液滴の浮揚（Bindal et al., 1984）, 二次元の超音波マ ニピュレーション（Takeuchi, 1996），赤血球の凝集（Yasuda et al., 1997）, 液滴の非接触分注（Tanaka et al., 2012）,

\footnotetext{
No.16-00031 [DDOI:10.1299/transjsme.16-00031], J-STAGE Advance Publication date : 30 August, 2016

${ }^{* 1}$ 正員, 茨城大学大学院 理工学研究科 (广316-8511 茨城県日立市中成沢町 4-12-1)

*2 正員, 茨城大学 工学部

E-mail of corresponding author: 13nd2011@vc.ibaraki.ac.jp
} 


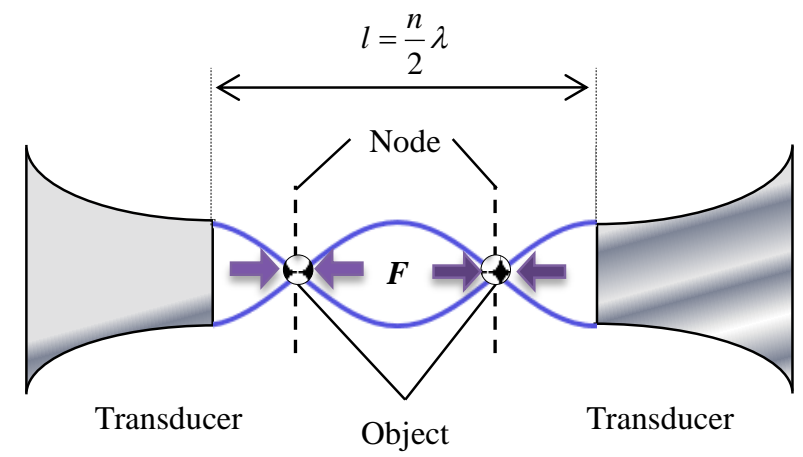

Fig. 1 Concept of acoustic levitation.

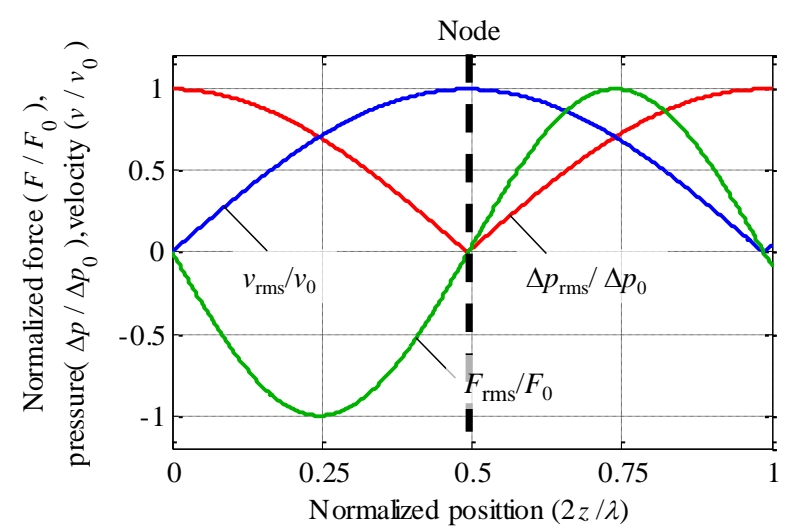

Fig. 2 Normalized wave field.

非接触溶融（Whymark, 1975）など様々な分野で応用研究が行われている.この音響浮揚技術を用いて物質の大き さに関係なく密度のみで分別することが可能であれば，混合物から資源となる金属などの分別，再利用が可能と なる．本論文では，まず廃棄物の分別に必要な定在波音場を発生するツイン振動子装置を開発し，浮揚力を含む 分別するために必要な条件を理論的に求めた．次にこの装置を用いて鉄 $(\mathrm{Fe}) \cdot$ 二酸化ケイ素 $\left(\mathrm{SiO}_{2}\right)$ の分別に関 する基礎実験を行い，本分別手法の妥当性について検証した．最後に，実際に OA 機器廃棄物を用いて密度によ る分別実験を行った．廃棄物に対し分別を繰り返し行い，分別の回数に伴う密度変化について調べた.

\section{2. 音響浮揚の理論}

音響浮揚の概要を図 1 に示寸. 振動子間の距離が半波長の整数倍の時, 音場に定在波が形成される (Hoeppner and Reinhart, 2000）振動子から出力される音響波を平面波としたとき，速度ポテンシャルФは以下の式で表される.

$$
\frac{d^{2} \Phi}{d z^{2}}=\frac{1}{c^{2}} \frac{d^{2} \Phi}{d t^{2}}
$$

ここで， $z$ は左側の振動子からの距離， $c$ は大気中における音速である $(c \approx 340 \mathrm{~m} / \mathrm{s})$. 式（1）より,

$$
\Phi=e^{j(\omega t-k z)}+e^{-j(\omega t-k z)}
$$

が求まる. ここで, $\omega$ は振動子の周波数, $k$ は波数 $(k=2 \pi / \lambda), j$ は虚数である. 右辺の第 1 項は, 右一の進行波

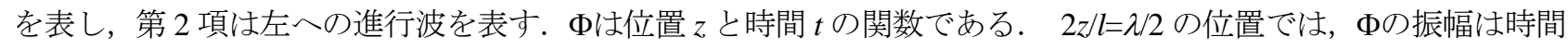
に関係なく常に 0 になり, 音圧ノードが生じる定在波になる.この場合, 粒子速度を $v$, 音圧の変化を $\Delta p$ とした とき，以下の式により求まる（早坂，吉川，1974）

$$
\left\{\begin{array}{l}
v=\nabla \Phi=C \cos \omega t \sin k z \\
\Delta p=\rho \frac{\partial \Phi}{\partial t}=\rho C \sin \omega t \cos k z
\end{array}\right.
$$

ここで， $\rho$ は粒子密度 (大気中では $\rho=1.293 \mathrm{~kg} / \mathrm{m}^{3}$ ), C は積分定数であり，振動子の初期条件から求まる．これら の時間平均を $v_{\mathrm{rms}}, \Delta p_{\mathrm{rms}}$ としたとき，それぞれの無次元に正規化にした音響場における分布を図 2 に示寸. 音圧 のノード位置 $(2 z / \lambda=0.5)$ において, 粒子速度 $v_{\mathrm{rms}}$ が最大になり，また音圧がゼロであるが，その変化率 $\left(\Delta p_{\mathrm{rms}}\right.$ の勾配）が最大になる。このため, 定在波音響場におかれた物体が音圧の差により浮力と，粒子速度の差により 揚力からなる浮揚力（合力）を受けて, 図 1 に示寸ようにノード位置へ移動することになる. このとき音場の 音響ポテンシャル $U$ は以下の式 (Gol'dberg, 1971) により求まる. 


$$
U=2 \pi r^{3} \rho\left[\frac{\Delta p_{r m s}{ }^{2}}{3 \rho^{2} c^{2}}-\frac{v_{r m s}{ }^{2}}{2}\right]
$$

ここで, $r$ は物体の半径である. 右辺第 1 項は浮力に対応し，第 2 項は揚力に対応している. 物体に作用寸る浮 揚力を $F$ とした時， $F=-\nabla U$ により，

$$
F=\frac{5}{3} \frac{r^{3} k \Delta p_{r m s}^{2} \pi}{\rho c^{2}} \sin 2 k z
$$

ここで, $\Delta p_{r m s}=\Delta p_{0} / \sqrt{2}, k=2 \pi f$ により式（5）を置き換えると，

$$
F=\frac{5}{3} \frac{\pi^{2}}{\rho c^{2}} r^{3} f \Delta p_{0}^{2} \sin 2 k z
$$

式（6）ようになる. それによれば，浮揚力 $F$ は，振動子の周波数 $f$, または音圧の変化量 $\Delta p_{0}$ の二乗に比例する.

\section{3. 分別装置の開発}

式 (2) に示すように半波長の整数倍の距離に置かれた 2 枚の平行平板の間に波長と振幅が同じの 2 つの波が共 振して定在波が生じる。これまで，平面振動子と硬質の平面反射板を用いて簡易的に試作した実験装置では，音 波が反射時に減衰するため定在波を正しく生成することが困難であった．本研究では，減衰の影響を極力抑える ため同期した 1 対の平面振動子を向かい合わせて分別装置を構築した．その概念図を図 3 に示す．装置はツイン 振動子とベルトコンベアから構成されており，振動子間に定在音響場が形成され，ベルトコンベアに載せた産廃 混合物が定速でその間を通過することができる仕組みになっている，定在波音響場に物体が入ると，物体は Z 軸 方向に浮揚力 $F$ を受け，ノード位置へ向かって移動する．物体とベルトコンベア間の摩擦の影響を無視すれば, この時物体の運動方程式は，ニュートン第二法則に従い，式（7）のように横軸（Z-axis）と縦軸（Y-axis）に分 けて記述できる.

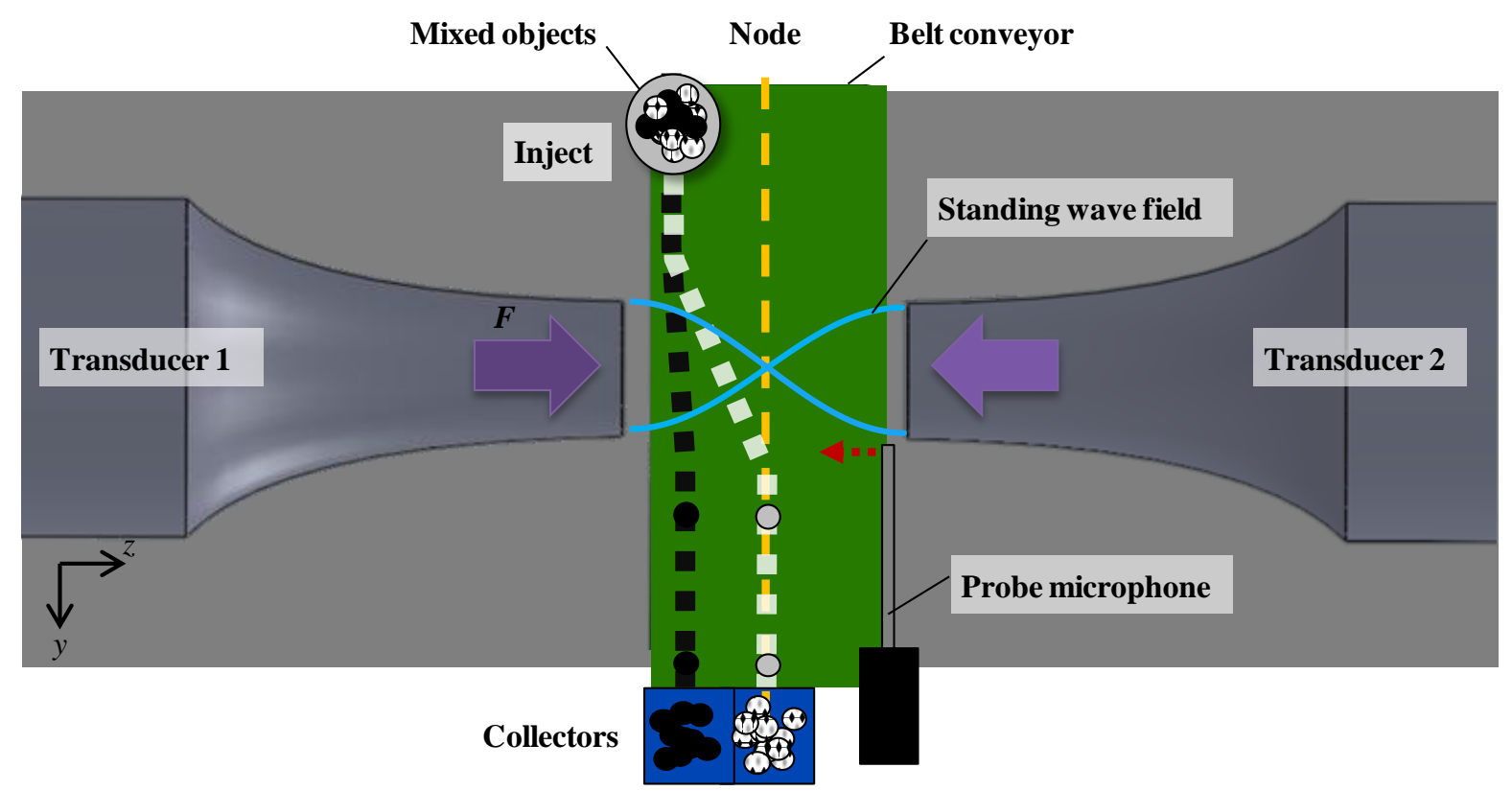

Fig. 3 This system is consisted of two transducers faced each other horizontally and belt conveyor. When objects which are fed at the anti-node pass through the field of the standing wave, they are subjected to the horizontal levitation force and move toward the node position. The lighter objects travel larger distance than the heavier objects. 


$$
\begin{cases}m z^{\prime \prime}(t)=\frac{5}{3} \frac{\pi^{2}}{\rho c^{2}} r^{3} f \Delta p_{0}^{2} \sin 2 k z(t) & \cdots(\mathrm{Z} \text { - axis }) \\ y(t)=v_{y} t & \cdots(\mathrm{Y} \text { - axis })\end{cases}
$$

ここで $m$ は物体の質量, $v_{y}$ は Y-axis におけるベルトコンベアの速度, $t$ は時間を表している. 今回の研究は, 工 業産廃物の中に含まれる金属をプラスチックなどから分離・回収することが目的であるため，高精度の計算を行 わなくても実現できることから，物体が Z 軸方向に移動する際に生じた物体同士の衝突，物体・ベルト間の摩擦 などの影響を無視した．また物体を球形と仮定し， $m=4 / 3 \rho_{s} \pi r^{3} \quad\left(\rho_{\mathrm{s}}\right.$ : 物体の密度）を式（7）に代入すると， 式（8）に変形できる.

$$
\begin{cases}z^{\prime \prime}(t)=\frac{5 \pi}{4 \rho c^{2}} \frac{f \Delta p_{0}^{2}}{\rho_{s}} \sin 2 k z(t) & \cdots(\mathrm{Z}-\text { axis }) \\ y(t)=v_{y} t & \cdots(\mathrm{Y}-\text { axis })\end{cases}
$$

式（8）に物体の大きさを示寸半径 $r$ が消去されたため，Z-axis における物体の移動距離 $z(t)$ は，物体の大きさ に関係がなく，密度 $\rho_{s}$ のみに依存することがわかる．この性質を利用すれば，金属，プラスチックのような異な る物質の分別が可能になる.ここで, ベルレ法を用いて式 (8) を解き, 音響場における物体の運動軌跡を求めた.

図 4 には, 幅が $20 \mathrm{~mm}$ の定在波音場を通過する密度の異なる 2 つの物体 $\mathrm{SiO}_{2}\left(\rho_{s}=2.1 \mathrm{~g} / \mathrm{m}^{3}\right)$ と $\mathrm{Fe} \quad\left(\rho_{s}=7.874\right.$ $\left.\mathrm{g} / \mathrm{m}^{3}\right)$ に対し, 音圧を $\Delta p_{0}=200,400,600 \mathrm{~Pa}$, 物体の Y-axis 方向の速度を $v_{y}=15,20 \mathrm{~mm} / \mathrm{s}$ と変化させた時の物体 の運動軌跡を示寸．密度の大きい $\mathrm{Fe}$ の微粒子に比べて, 密度の小さい $\mathrm{SiO}_{2}$ の微粒子はアンチノード位置からよ り早くノード位置へと移動していることがわかる. 2 つの物体の密度に従って, 音圧 $\Delta p_{0}$ と Y-axis 方向の速度 $v_{y}$ を適切に調整すれば, 音響場出口のところにおける 2 者の距離 $d$ を大きくして分離することができる.

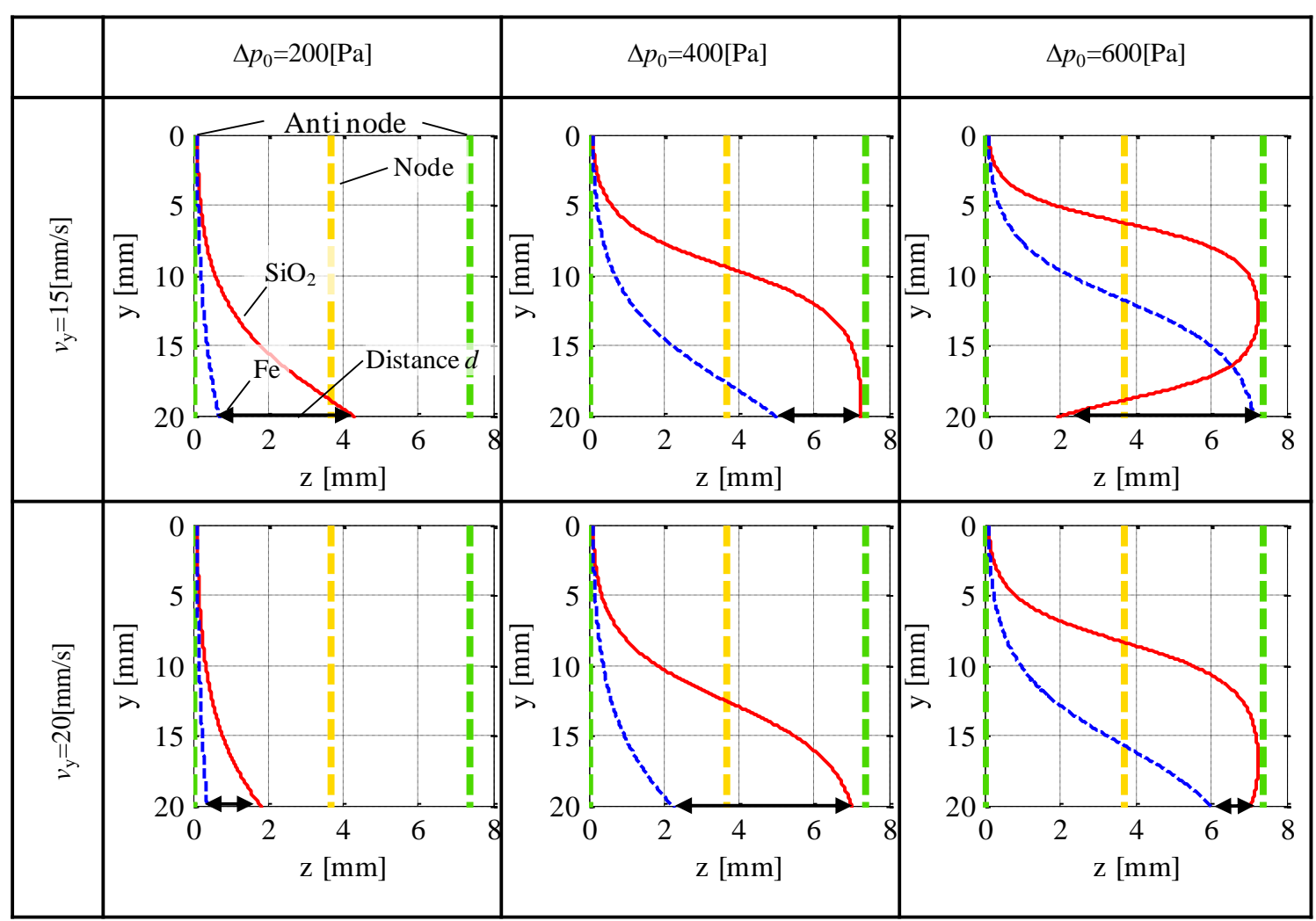

Fig. 4 Travelling trajectory of $\mathrm{SiO}_{2}$ and $\mathrm{Fe}$ particles at standing wave acoustic field. 


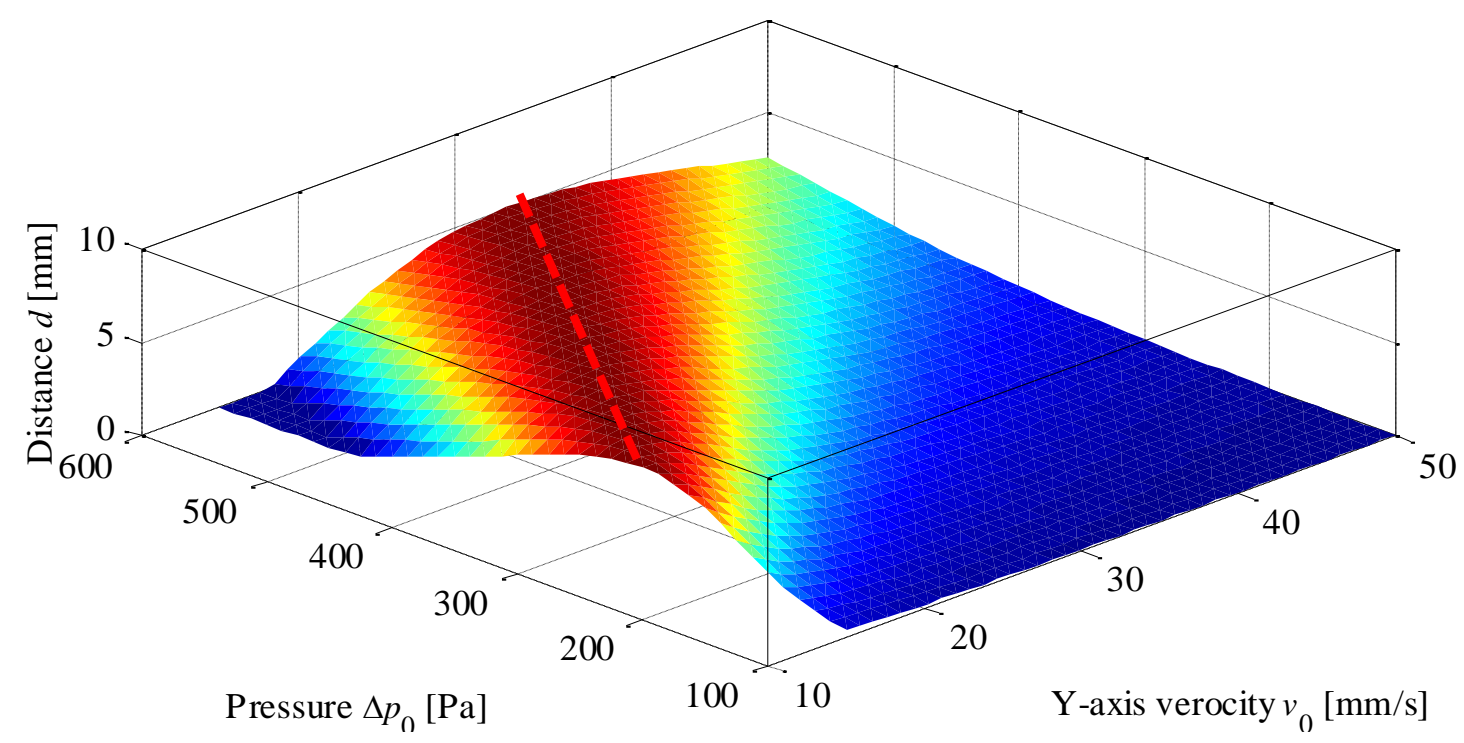

Fig. 5 Distance $d$ at exit as a function of $\Delta p_{0}$ and $v_{y}$.

図 5 は，図 4 のシミュレーション結果を $3 \mathrm{D}$ マップで表している. 出口における 2 つ物体間の距離 $d$ は，音 圧 $\Delta p_{0}$ とベルト速度 $v_{y}$ に依存している．本シミュレーションにおいては，dの最大值はおよそ $5 \mathrm{~mm}$ 程度で，後 に述べる開発した装置で生成した定在波の $\lambda / 4 \sim \lambda / 2$ に相当する. また図中の破線で示すように，物体間の距離 が最大となる音圧 $\Delta p_{0}$ とベルト速度 $v_{y}$ は比例関係になっている．とのためベルトの速度を早くする場合は同時に 音圧も大きくする必要がある.

図 6 は，このコンセプトに従って開発した分別装置の写真で，表 1 は分別装置の仕様を示している. 本装置で は先端直径 $\phi 20 \mathrm{~mm}$ のランジュバン振動子を対になるように設置し，定在波を形成する．振動子は約 $23 \mathrm{kHz} て ゙$ 駆

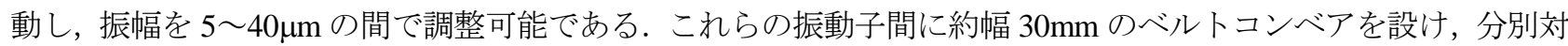
象物を載せて通過させることで，一定時間浮揚力を加えて分別する. 開発した分別装置の音響場音圧変化は振動 子間に細長い音圧プローブを挿入して（図 3 参照）実測した。図 7 は Y-Z 平面における音圧分布を実測した例 $\left(\Delta p_{0}=300 \mathrm{~Pa}\right)$ である.Z 軸における音圧の強弱が交互に存在し，5つの音圧ノードを確認できる定在波が形成 されている．また，音波の強度が左右対称であり，ツイン振動子によって音波強度の減衰が効果的に抑制されて いることがわかる.

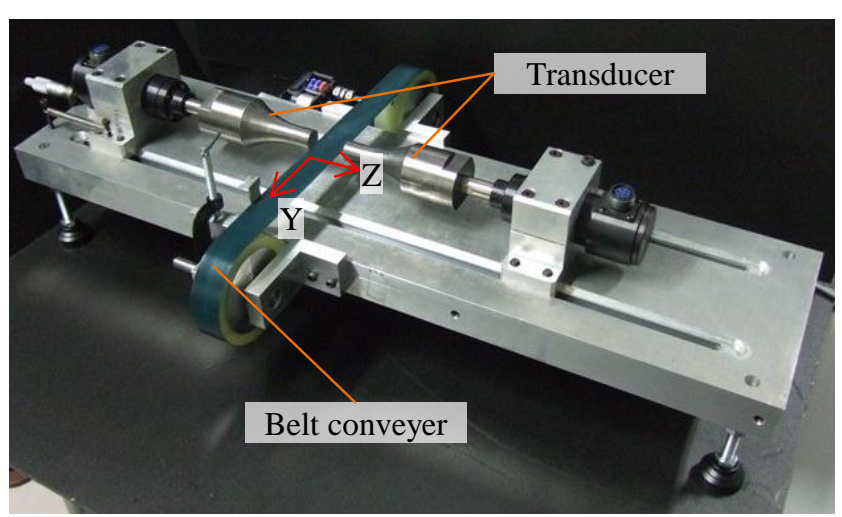

Fig.6 Developed system.
Table 1 Specifications of developed system.

\begin{tabular}{|c|c|c|}
\hline \multirow{4}{*}{ Transducer } & Frequency & $\mathbf{2 3} \pm \mathbf{2}[\mathbf{k H z}]$ \\
\cline { 2 - 3 } & Amplitude & $5 \sim 40[\mu \mathrm{m}]$ \\
\cline { 2 - 3 } & Phase & $-100 \sim+100 \quad\left[{ }^{\circ}\right]$ \\
\cline { 2 - 3 } & Tip diameter & $\phi 20[\mathrm{~mm}]$ \\
\cline { 2 - 3 } & $\begin{array}{c}\text { Transducer } \\
\text { type }\end{array}$ & $\begin{array}{c}\text { Bolt-clamped } \\
\text { langevin transducer }\end{array}$ \\
\cline { 2 - 3 } $\begin{array}{c}\text { Belt } \\
\text { conveyor }\end{array}$ & Function & $\begin{array}{c}\text { Phase synchronizer, } \\
\text { Automatic resonant } \\
\text { frequency tracing }\end{array}$ \\
\cline { 2 - 3 } & Material & Polyurethane \\
\cline { 2 - 3 } & Width & $30[\mathrm{~mm}]$ \\
\hline \multirow{4}{*}{\begin{tabular}{c} 
Velocity \\
\hline
\end{tabular}} & $5 \sim 45[[\mathrm{~mm} / \mathrm{s}]]$ \\
\hline
\end{tabular}




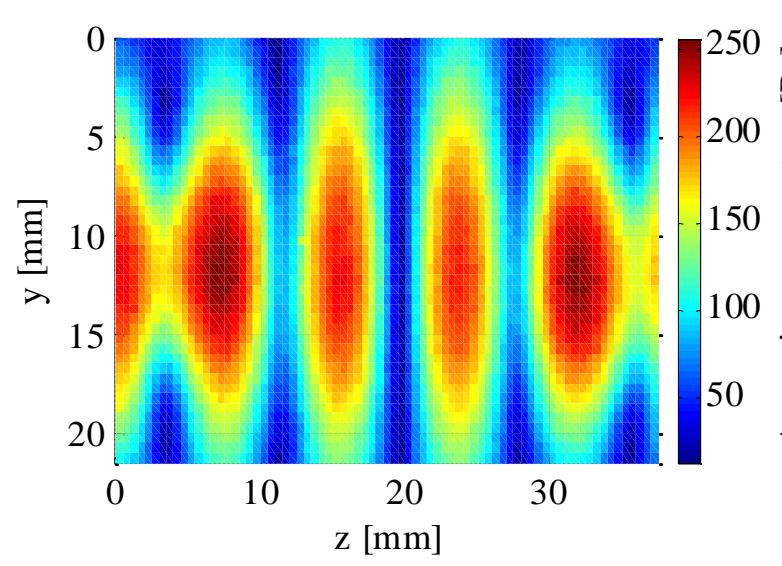

Fig. 7 Measured acoustic pressure distribution.
Table 2 Particles used for sorting test.

\begin{tabular}{|c|c|c|}
\hline Material & $\mathrm{SiO}_{2}$ & $\mathbf{F e}$ \\
\hline Media & & \\
\hline Diameter & $r=50[\mu \mathrm{m}]$ & $r=50[\mu \mathrm{m}]$ \\
\hline Density & $2.100\left[\mathrm{~g} / \mathrm{cm}^{3}\right]$ & $7.874\left[\mathrm{~g} / \mathrm{cm}^{3}\right]$ \\
\hline Quantity & $0.1[\mathrm{~g}]$ & $0.4[\mathrm{~g}]$ \\
\hline
\end{tabular}

\section{4. 分別実験}

開発した分別装置の性能を検証するため, 密度が既知の 2 種類の微粒子 $\left(\mathrm{SiO}_{2}, \mathrm{Fe}\right)$ を用いて分別試験を行っ た．表 2 には使用した 2 種類の微粒子の仕様を示す．まず， $\mathrm{SiO}_{2}$ をコンベアに一様分布させて，振動子間を通過 させた時の写真を図 8 に示す.この時の音圧は $\Delta p_{0}=300 \mathrm{~Pa}$, コンベア速度は $v_{y}=20 \mathrm{~mm} / \mathrm{s}$ であり, $\mathrm{SiO}_{2}$ は振動子 間に形成された定在波音場によってノード位置に移動する様子が確認できる.これらの間隔は約 $7.4 \mathrm{~mm}$ であり， 周波数 $23 \mathrm{kHz}$ の定在波の $\lambda / 2$ に相当する. これにより第 2 章に述べたように，定在音響場において物体が浮揚力 の作用によってノード位置に移動したことが確認された.

次に，体積が同じになるように $\mathrm{SiO}_{2}$ を $0.1 \mathrm{~g}, \mathrm{Fe}$ を $0.4 \mathrm{~g}$ で混ぜ合わせた混合物をアンチノード位置から供給し て, コンベア速度を $v_{y}=20 \mathrm{~mm} / \mathrm{s}$, 音圧を $\Delta p_{0}=300,600 \mathrm{~Pa}$ の 2 段階で変化させて分別試験を行った. 図 9 は音 圧 300Pa で分別中の写真であり, 図 4 のシミュレーションと同様にアンチノード側に置かれた $\mathrm{Fe}$ と $\mathrm{SiO}_{2}$ の混合 体から, 密度の小さい $\mathrm{SiO}_{2}$ だけがノード位置へと移動しているのが確認できる. 図 10 は分別後それぞれアンチ ノード側 (左), ノード側（右）から回収された微粒子である. 磁石を用いてそれらの成分を調べたところ, 密度 の小さい $\mathrm{SiO}_{2}$ は $62 \mathrm{wt} \%$ がノド位置に移動したのに対し, 密度の大きい $\mathrm{Fe}$ は $72 \mathrm{wt} \%$ がアンチノード側に残って いることがわかった. アンチノード位置で回収した微粒子について， $\mathrm{SiO}_{2}, \mathrm{Fe}$ の成分を計測して得られたそれぞ れの供試品に対する重量比を図 11 に示寸．音圧 300Pa では，アンチノード側に $\mathrm{Fe}$ が多く残り, $\mathrm{SiO}_{2}$ のノードー の移動量が Fe の移動量と比較し, $35 \mathrm{wt} \%$ 多くなった. これにより, 浮揚力を利用して素材の密度による分別・分 類が可能であることが実証できた.
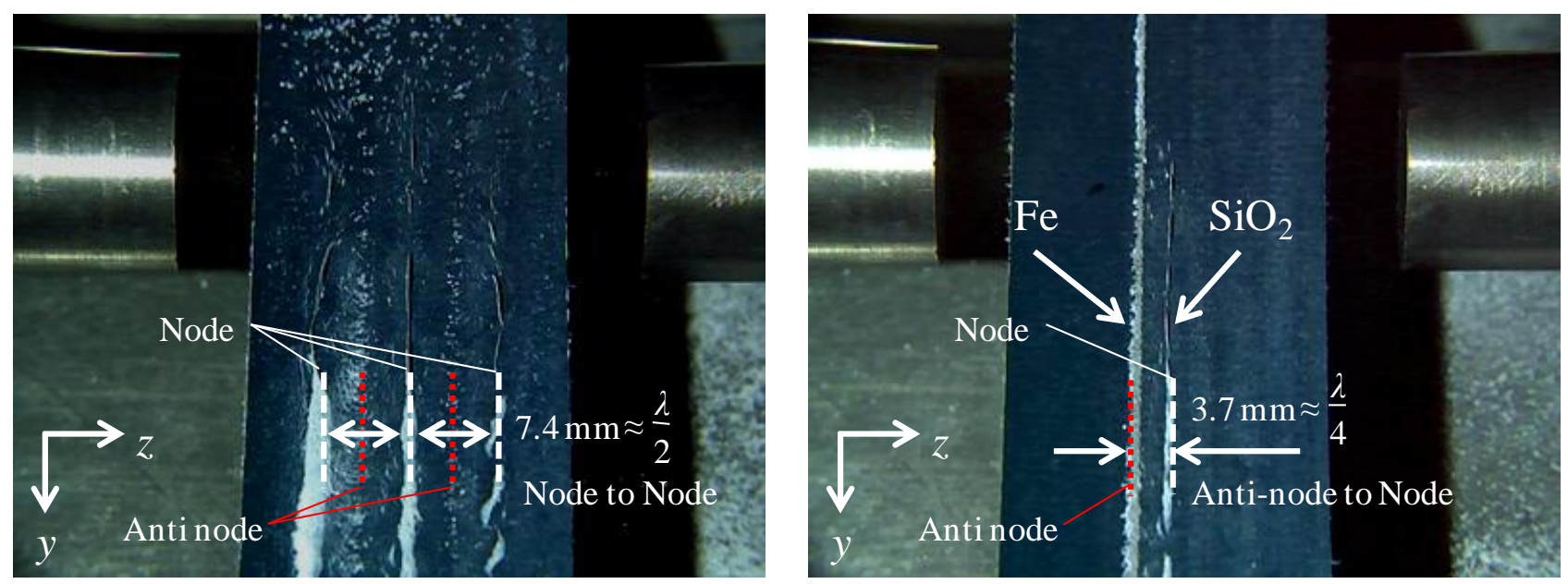

Fig. $8 \quad \mathrm{SiO}_{2}$ gathering at the node positions.

Fig. 9 After passing through acoustic field, mixed $\mathrm{SiO} 2$ and $\mathrm{Fe}$ particles are separated by acoustic levitation force. 


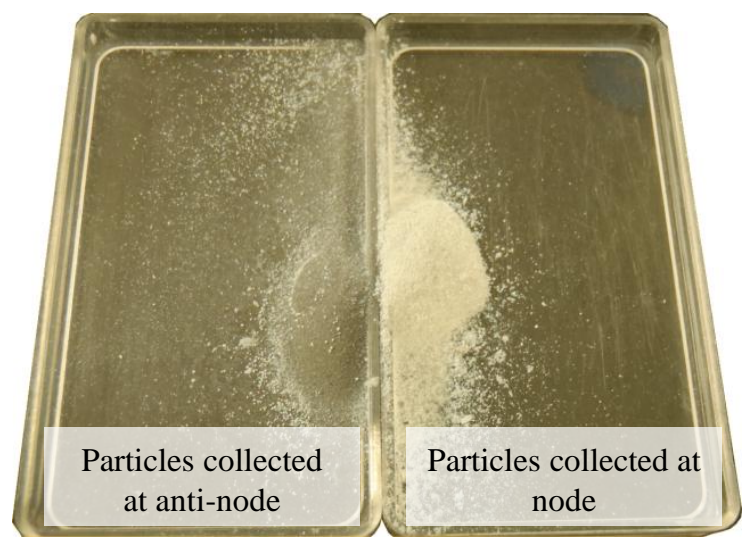

Fig. 10 Sorted $\mathrm{SiO}_{2}$ and $\mathrm{Fe}$ particles.

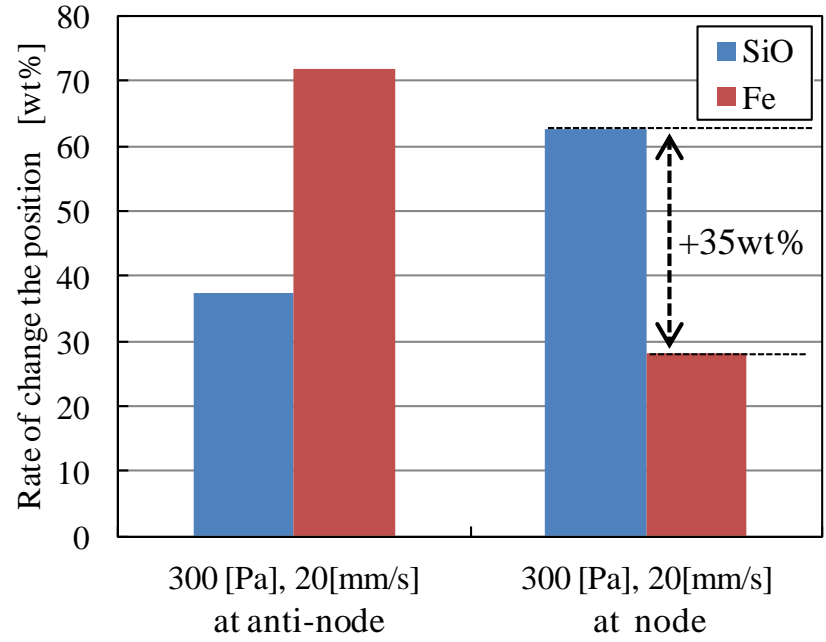

Fig. 11 Rate of particle collected at node and anti-node. $72 \mathrm{wt} \%$ of $\mathrm{Fe}$ stayed at anti node, and $62 \mathrm{wt} \%$ of $\mathrm{SiO}_{2}$ moved to the node which is $35 \mathrm{wt} \%$ more than Fe.

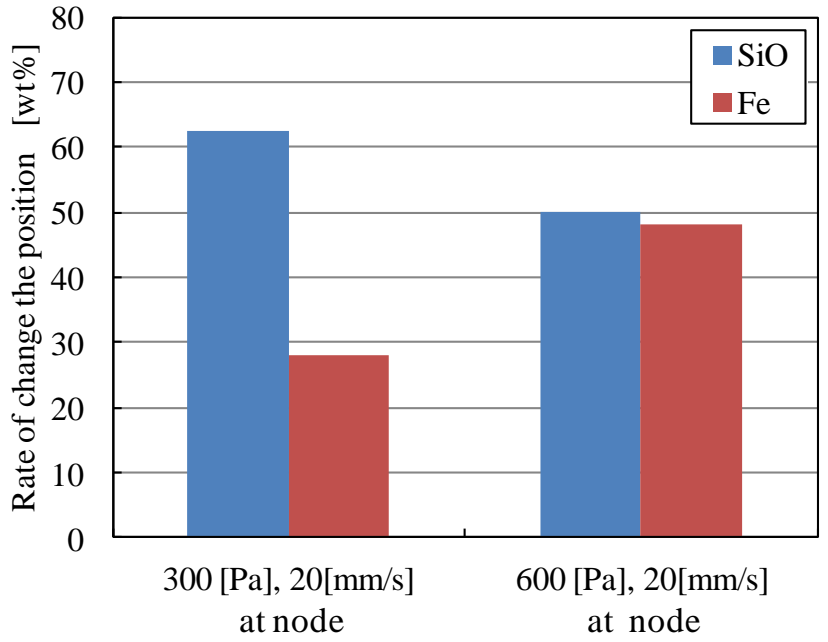

Fig.12 Rate of particle collected at the node position under different acoustic pressures. It is important to match the belt velocity with the acoustic pressures properly.

一方図 12 において音圧を $600 \mathrm{~Pa}$ まで上昇させたときに得た結果を併示した，その場合， $\mathrm{SiO}_{2}$ だけではなく約 50wt\%の Fe の微粒子もノード位置に移動した。この結果は, 図 4, 5 のシミュレーション結果と一致しており, 過度の音圧は音響場出口における 2 者間距離 $d$ を小さくする恐れがある. したがって, 距離 $d$ を大きくする音圧 とベルト速度の組み合わせが，密度分別の肝要である．また，本装置では本来 $300 \mathrm{~Pa}$ で移動しない $\mathrm{Fe}$ の一部が $\mathrm{SiO}_{2}$ に引きずられてノード側に移動しているが，分別対象に合わせて流量の調整，繰り返し分別を行うことで分 別精度向上が期待できる.

最後に, 産廃業者から提供された実際の工業産廃物（細かく粉砕した $\mathrm{OA}$ 機器）に対して, 分別試験を行った。 産廃物の大きさ, 形状, 密度などが不明であり, また先述の $\mathrm{Fe} や \mathrm{SiO}_{2}$ 等と異なり, 形状も球形ではないため, 分別条件の最適化が難しい. 一方で移動量が密度に依存するという原理は同じであるため，ここでは産廃物の単 価が密度とともに上昇することから, 開発した装置を用いてアンチノード位置で回収した密度の大きい成分を再 度開発装置に通して繰り返し分別実験を実施し, 各回の分別による廃棄物の密度の変化を調べた。初期密度 $800 \mathrm{~kg} / \mathrm{m}^{3}, 950 \mathrm{~kg} / \mathrm{m}^{3}$ の 2 種類の廃棄物を供試品として用意した。産業廃棄物の密度は質量, 体積の計算值から求 めており, 質量は電子天びん, 体積はシリンダに入れて計測した。ここでの体積はかさ体積であり, 産廃物の密 度が実際よりも小さくなると考えられるため, 初期密度と相対比較を行う. 図 13 は初期密度 $800 \mathrm{~kg} / \mathrm{m}^{3}$ の廃棄物 の分別前， 3， 7 回分別後のアンチノード位置で回収した成分の比較写真である. 分別前廃棄物は, サイズがおよ そ $1 \mathrm{~mm}$ 以下，大きさ，形状などが揃っていない様子がわかる．分別回数が増えるに連れ，貴金属の占める割合 が増え，黒色を呈するようになった。 


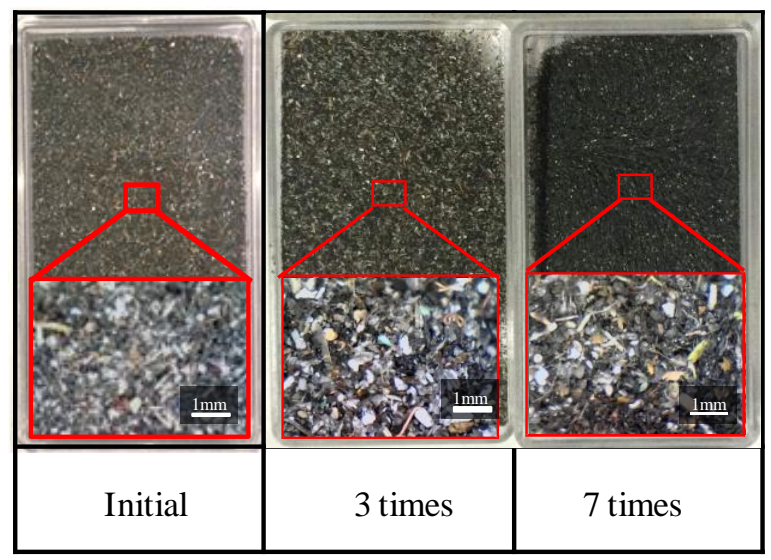

Fig. 13 Visual impression of sorted industrial waste.

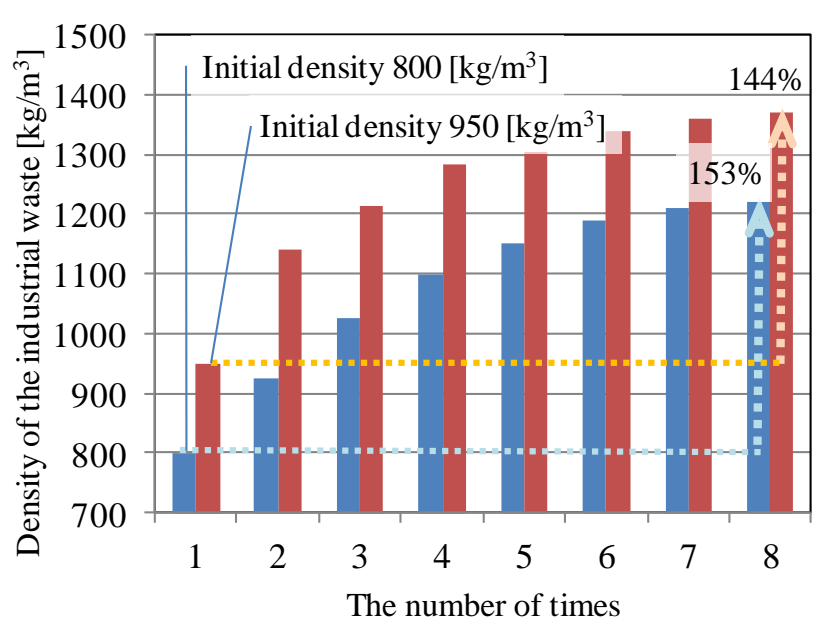

Fig. 14 Density variation of industrial waste by repeated-sorting.

困 14 は初期密度 $800 \mathrm{~kg} / \mathrm{m}^{3}$ と $950 \mathrm{~kg} / \mathrm{m}^{3}$ の 2 種類の OA 廃棄物を繰り返し 7 回分別した時の密度の变化を示し ている. 7 回分別後の密度は $800 \mathrm{~kg} / \mathrm{m}^{3}$ から $1220 \mathrm{~kg} / \mathrm{m}^{3}$ に, $950 \mathrm{~kg} / \mathrm{m}^{3}$ から $1370 \mathrm{~kg} / \mathrm{m}^{3}$ となり, 初期密度と比較して それぞれ $153 \% ， 144 \%$ 上昇した. 密度の上昇率は 2 種類共に 1 回目が最も大きく，回数を重ねるごとに少しずつ 上昇率が小さくなった。これは繰り返し分別を行うことで産業廃棄物内の密度の小さい物体の含有率が減ったこ とが原因と考えられる。

\section{5. 結 言}

本論文は産業廃棄物から再利用可能な貴金属を回収する方法として音響浮揚の技術を応用した分別方法を提案 し，理論および実験により本手法の妥当性について検証した。得られた結果を次のようにまとめる.

（1）音響浮揚の原理に基づき定在音響場における物体が受ける浮揚力を理論的に解析し，それを受けた物体の 運動は大きさには関係なく密度の夕に依存することを明らかにした。

（2）密度の異なる物体の移動軌跡についてシミュレーションを行い，音圧，物体の移動速度を適切に制御すれ ば，密度による分別が可能であることを確認した。

（3）上記の解析結果に基づき，ツイン振動子とベルトコンベアからなる分別装置を設計・開発した.

（4）密度が既知である 2 種類の $\mathrm{SiO}_{2}$ と $\mathrm{Fe}$ の微粒子の分別試験を行い， $62 \mathrm{wt} \%$ の $\mathrm{SiO}_{2}$ がノード位置に，72wt $\%$ の Fe はアンチノード位置に捕捉された.

（5）実際の OA 機器廃棄物に対し, 開発装置を使って密度分別を7回繰り返し行い, 廃棄物の密度をおよそ $150 \%$ 上昇させることができた.

謝 辞

本研究の一部は, 科学研究費「挑戦的萌芽研究」（No. 24656094）の助成によって行われたことを記し謝意を表 す.

文献

荒木孝雄, 阿川隆一, 次田康裕, 廃プリント配線板からの金属回収の最新技術, エレクトロニクス実装学会誌, Vol.8, No.5 (2005), pp.442-446.

Bindal, V. N., Jain, S. K., Saksena, T. K. and Singth, G., Acoustic levitation and its application in estimation of high power sound field, Applied Acoustics, Vol.17 (1984), pp.125-133.

Gol'dberg, Z. A., Acoustic radiation pressure in high-intensity ultrasonic fields, L. D. Rozenberg, Ed (1971), p.73.

早坂寿雄, 吉川昭吉郎, 音響振動論, 丸善 (1974), pp.455-469. 
Hoeppner, J. and Reinhart, G., Non-contact handling using high-intensity ultrasonic, Annals of the CIRP, Vol.49 (2000), pp.5-8.

Inada, T., Zhou, L., Shimizu, J., Ojima, H. and Ito, T., Development of non-contact classifying systems by use of acoustic levitation, Int. J. of Automation Technology, Vol.6, No.7 (2013), pp.326-331.

環境省, 産業廃棄物の排出及び処理状況等, 記者発表資料(2014), pp.1-8.

竹内正男，微小物体の超音波マイクロマニピュレーション(く小特集〉力としての超音波)，日本音響学会誌，Vol.52， No.3 (1996), pp.203-209.

田中宏樹, 和田有司, 水野洋輔, 中村健太郎, 超音波による液滴の非接触分注(強力超音波,一般), 電子情報通信学 会技術研究報告. US, 超音波, Vol.112, No.366 (2012), pp.29-34.

Whymark, R. R., Acoustic field positioning for containerless processing, Ultrasonics, Vol.13 (1975), pp.251-261.

Yasuda, K., Haupt, S. S., Umemura, S., Yagi, T., Nishida, M. and Shibata, Y., Using acoustic radiation force as a concentration method for erythrocytes, Acoustical Society of America, Vol.102 (1997), pp.642-645.

\section{References}

Araki, T., Agawa, R. and Tugita, Y., Recent recycling technology of metals separation for waste printed circuit boards, Japan Institute of Electronics Pckaging (JTEP), Vol. 8, No.5 (2005), pp.442-446 (in Japanese).

Bindal, V. N., Jain, S. K., Saksena, T. K. and Singth, G., Acoustic levitation and its application in estimation of high power sound field, Applied Acoustics, Vol.17 (1984), pp.125-133.

Gol'dberg, Z. A., Acoustic radiation pressure in high-intensity ultrasonic fields, L. D. Rozenberg, Ed (1971), p.73.

Hayasaka, T. and Yoshikawa, S., Logical acoustic oscillation, Maruzen (1974), pp.455-469 (in Japanese).

Hoeppner, J. and Reinhart, G., Non-contact handling using high-intensity ultrasonic, Annals of the CIRP, Vol.49 (2000), pp.5-8.

Inada, T., Zhou, L., Shimizu, J., Ojima, H. and Ito, T., Development of non-contact classifying systems by use of acoustic levitation, Int. J. of Automation Technology, Vol.6, No.7 (2013), pp. 326-331.

Ministry of the Environment, Discharge and treatment of industrial waste, Press Release (2014), pp.1-8 (in Japanese).

Takeuchi, M., Ultrasonic micromanipulation of micron-sized particles, The Acoustical Society of Japan, Vol.52, No.3 (1996), pp.203-209 (in Japanese).

Tanaka, H., Wada, Y., Mizuno, Y., Nakamura, K., Non-contact dispensing of small droplets through ultrasonic levitation, IEICE technical report. Ultrasonics, Vol.112, No.366 (2012), pp.29-34 (in Japanese).

Whymark, R. R., Acoustic field positioning for containerless processing, Ultrasonics, Vol.13 (1975), pp.251-261.

Yasuda, K., Haupt, S. S., Umemura, S., Yagi, T., Nishida, M. and Shibata, Y., Using acoustic radiation force as a concentration method for erythrocytes, Acoustical Society of America, Vol.102 (1997), pp.642-645. 